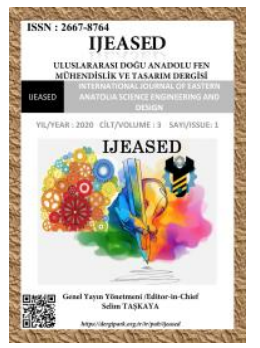

IJEASED INTERNATIONAL JOURNAL OF EASTERN ANATOLIA SCIENCE ENGINEERING AND DESIGN

\author{
Uluslararası Doğu Anadolu Fen Mühendislik ve Tasarım Dergisi \\ ISSN: 2667-8764, 3(1), 221-239, 2021 \\ https://dergipark.org.tr/tr/pub/ijeased
}

Araştırma Makalesi / Research Article

Doi: $\underline{10.47898 / \text { ijeased.822938 }}$

\title{
Karabük İli Ovacık İlçesi Kırsal Yerleşimlerindeki Geleneksel Konutların Cephe Özellikleri
}

\author{
Elif ÇETIN ${ }^{1 *}$, Mehmet MUTLU ${ }^{2}$
}

${ }^{1}$ Karabük Üniversitesi, Mimarlık ABD, Karabük, 78600, Türkiye.

${ }^{2}$ Karabük Üniversitesi, Mimarlık Bölümü, Karabük, 78600, Türkiye.

\begin{tabular}{l|l|l}
\hline \multicolumn{1}{c|}{ Yazar Kimliği / Author ID (ORCID Number) } & \multicolumn{1}{|c}{ Makale Süreci / Article Process } \\
\hline "Sorumlu Yazar / Corresponding author : & Geliş Tarihi / Received Date $:$ & 07.11 .2020 \\
elfctnnn@gmail.com & Revizyon Tarihi / Revision Date : & 06.03 .2021 \\
\hline iD https://orcid.org/0000-0003-2037-9807, E. Çetin & Kabul Tarihi / Accepted Date : & 22.03 .2021 \\
iD https://orcid.org/0000-0002-7351-0138, M. Mutlu & Yayım Tarihi / Published Date : & 15.07 .2021 \\
\hline
\end{tabular}

Alıntı / Cite : Çetin, E., Mutlu, M. (2021). Karabük İli Ovacık İlçesi Kırsal Yerleşimlerindeki Geleneksel Konutların

Cephe Özellikleri, Uluslararası Doğu Anadolu Fen Mühendislik ve Tasarım Dergisi, 3(1), 221-239.

\section{Özet}

Karabük iline bağlı Ovacık ilçesinde, geleneksel mimari dokusunu koruyabilmiş çok sayıda yerleşim yeri bulunmasına rağmen, ilçe genelinde mimarlık bağlamında yapılmış akademik çalışma sayısı oldukça azdır. Ovacık ilçesi ve köyleri; işsizlik, eğitim, sağlık, sosyal imkânların yetersizliği gibi nedenlerden dolayı genç nüfusunu kaybetmektedir. Bu tür sorunlarla birlikte kırsal yerleşimlerde, mevcut konutlar günümüz ihtiyaçlarına cevap veremediğinden terk edilmektedir. Köyde yaşantısını sürdürmeye çalışan yerel halkın ya bu konutları tadilatla günümüz şartlarına uydurmaya çalıştığı ya da imkânı varsa yeni bir konut inşa etme çabasına girdiği gözlemlenmiştir. Kırsal yerleşimlerde yer alan konutlar, yakın çevrede var olan malzemeler kullanılarak yerel yapı ustaları tarafından inşa edilmiştir. Geleneksel konutların büyük çoğunluğunda yapım sistemi; yığma sistem üzeri ahşap karkas şeklindedir. Konutların çatıları; kırma, beşik veya üç omuz şeklinde olup özgün örneklerde alaturka kiremitle kaplanmıştır. Pencereler; ahşap malzemeden, giyotin veya kanatlı pencere olarak yapılmıştır. Konutların giriş kapıları tek veya çift kanatlı olarak değişkenlik göstermektedir. Açık çıkma örneklerine az sayıda konutta rastlanırken, kapalı çıkma yapılan konut sayısı oldukça fazladır. Genellikle kuzey cephede yer alan hela ve abdestlik mekanları çıkma şeklinde yapıya eklenmiştir. Yapıların çoğu sıvasız olduğu için taşıyıcı sistem kurgusu rahatlıkla gözlenebilmektedir. Cepheler; süslemeden uzak, oldukça sade tutulmuştur. Bu çalışmayla, Ovacık ilçesinin geleneksel konutlarının cephe özelliklerinin irdelenmesi ve sahip oldukları yöresel özelliklerin ortaya çıkartılması amaçlanmıştır.

Anahtar Kelimeler: Karabük, Ovacık, Kırsal yerleşimler, Geleneksel konut, Cephe özellikleri. 


\title{
Facade Features of Traditional Houses in Rural Settlements of Ovacik District of Karabuk Province
}

\begin{abstract}
Although there are many settlements that have preserved their traditional architectural texture in Ovacik district of Karabük province, the number of academic studies made in the context of architecture throughout the district is quite low. Ovacik district and its villages; loses its young population due to unemployment, education, health, insufficient social opportunities. With such problems, existing residences in rural settlements are abandoned because they cannot meet today's needs. It has been observed that the local people who try to continue their lives in the village either try to adapt these houses to today's conditions by renovating them or try to build a new house if they can. Residences in rural settlements were built by local builders using materials available in the vicinity. The construction system in the vast majority of traditional residences; The masonry system is in the form of a wooden carcass. Roofs of residences; in the form of crushed, cradle or three shoulders and covered with Turkish style tiles in original examples. Windows; It is made of wooden material, as a guillotine or casement window. The entrance doors of the residences vary as single or double wing. While examples of open cantilevers are encountered in a small number of houses, the number of houses with closed cantilevers is quite high. Generally, the toilet and ablution areas on the north facade were added to the building in the form of a protrusion. Since most of the buildings are without plaster, the carrier system setup can be easily observed. Fronts; It is kept very simple, far from decoration. With this study, it is aimed to examine the facade features of the traditional houses of Ovactk district and to reveal their local features.
\end{abstract}

Keywords: Karabük, Ovacı, Rural settlements, Traditional housing, Facade features.

\section{Giriş}

Geleneksel Türk konutları kendilerine has özellikleriyle fark ortaya koyarken, bu fark planlama ve oda düzeninin yanı sıra konutların cephelerinde de kendisini gösterir. Türk konutunun ayırıcı özelliklerinden birçoğunu, konutun cephe özelliklerinden anlamak mümkündür. Öyle ki yapının esasını teşkil eden odaların aydınlatma aracı olan pencereleri, gerek plandaki çarpıklıkları gidermek için ve gerekse kullanılan alanı büyütmek amacıyla yapılan çıkmaları ve bu çıkma desteklerini, konuta girişi sağlayan ana kapıyı ve konutun dış etkenlerden korunması amacıyla inşa edilmiş bulunan çatısı başta olmak üzere birçok özelliğini cepheden izlemek mümkündür.

Türk konutlarının coğrafi dağılımlarına bakıldığında plana yansıyan yerel özelliklerin aynı zamanda yapının cephesine de yansıdığı görülür. Bu sebeple farklı bölgelerde inşa edilmiş olan geleneksel konutlar her ne kadar planlama özellikleri olarak bir ortak noktada birleşseler de özellikle cephe özellikleri açısından birbirlerine göre önemli farklılıklar ortaya koyarlar.

Safranbolu ilçesi, Karabük il sınırları içerisinde, geleneksel mimari özellikleriyle ön plana çıkmış ve 1994 yılında UNESCO Dünya miras listesine dahil olarak gerek yurt içinde ve gerekse yurt dışında haklı bir üne ulaşmış bir yerleşim yeridir. Ancak Karabük'ün geleneksel mimari değerleri sadece Safranbolu ilçesiyle sınırlı değildir. Karabük'ün hemen hemen tüm ilçelerinde geleneksel ve yerel mimari özellikler barındıran ve halen özgünlüğünü sürdürmekte olan yerleşim yerleri bulunmaktadır. Ovacık ilçesi de bu yerleşimlerden bir tanesidir. Ovacık ilçesinde nüfus günden güne 
azalmaktadır. Hem bunun bir sonucu olarak hem de mevcut konutlar günümüz ihtiyaçlarına cevap veremediğinden, geleneksel konutlar hızlı bir şekilde kaderlerine terk edilmektedir. Köyde yaşantısını sürdürmeye çalışan yerel halkın bu konutları tadilatla günümüz şartlarına uydurmaya çalışması ya da imkânı varsa yeni bir konut inşa etme çabasına girmesi, kırsal mimari dokusunun hızla yok olma sürecine girmesini beraberinde getirmektedir. Konutlara yapılan bilinçsiz müdahaleler yapının özgünlügünü zedelemekte, yeni yapılan binalar ise kırsal yaşamın dokusuna aykırı bir şekilde köylerde kendini göstermektedir. Arazi çalışmaları sırasında tespit edilen yukarıda sayılan olumsuz nedenlerden bazıları konutun planının değişmesi sonucunu beraberinde getirirken, konuta yapılan bazı müdahaleler ise konutun geleneksel özelliklerini izleme imkânı bulabildiğimiz cephesinde de değişiklikler olarak karşımıza çıkmaktadır.

Ovacık ilçesini geleneksel mimari açısından konu eden çalışma sayısı oldukça sınırlıdır. 2018 yılında Avlağıkaya köyünün yöresel mimarisini ve kültürel değerlerini konu edinen bir sempozyum bildirisi (Özköse, 2018) ile 2019 yılında Ovacık ilçesinin en büyük köylerinden bir tanesi olan Dudaş köyünün geleneksel konut mimarisini incelendiği tez çalışması (Çetin, 2019) yapılmıştır. Bu çalışma ise Ovacık geleneksel konutlarının cephe özelliklerinin ele alındığı ilk ve tek çalışma olması açısından önem taşımaktadır.

Çalışma kapsamında Ovacık ilçesinin önemli kırsal yerleşimleri arasında bulunan Gümelik, Dudaş, Boyalı, Yığınot, Avlağıkaya, Küçüksu, Çukur, Başboyunduruk ve Sofuoğlu köyleri yerinde incelenmiş ve fotoğraflanarak belgeleme çalışması yapılmıştır. Alan çalışması esnasında dikkat çekici özellikleriyle ön plana çıkan örnekler cephe düzeni, kat sayısı, kapılar, pencereler, çıkmalar ve üst örtü alt başl1klarında değerlendirilerek, cephe düzenini meydana getiren bu unsurlarda zaman içinde oluşan değişim ve bozulmalar ayrı bir başlık altında değerlendirilmiştir.

$\mathrm{Bu}$ çalışmada Ovacık ilçesi kırsal yerleşimlerinde özgünlüğünü koruyabilmiş geleneksel konutların cephe özellikleri incelenmiştir. Geleneksel mimarlık üzerindeki çalışmalar, bölge, kültür ve iklim gibi nedenler başta olmak üzere farklı etkilerle özgün ve çoğunlukla da alışa gelmişlikten farklı detaylar barındırdığı için değerlidir. Bu çalışma, ilçede daha önce benzer bir araştırma yapılmamış olması açısından önemli olup, çalışma ile ilçenin geleneksel mimarlık dokusuna dikkat çekilmesi amaçlanmıştır. 


\section{Geleneksel Türk Evinde Cephe}

Geleneksel Türk evlerinin büyük çoğunluğu bir ya da iki kattan oluşmaktadır. Sedad Hakk1 Eldem'e göre Türk evi tek kattan oluşurken zaman içerisinde kat adedi artmıştır. Kat adedi artsa da esas kullanılan kat, tek kattan oluşmaktadır. Birkaç katlı evlerde esas kat en yukardaki kattır. En basit ev tipleri ise tek katlıdır. Tek kat zeminden en az bir buçuk metre yükseltilerek oluşturulmuştur. Bir kattan daha çok katlı konutlarda zemin katın servis alanı olarak kullanılmasından dolayı bu kısmın cepheye yansıması da oldukça sadedir. Üst kat ise yaşam alanı olarak kullanıldığı için cepheye daha hareketli bir şekilde yansımıştır (Eldem, 1984).

Çıkmalar, konutun cephedeki görünümünü etkileyen en önemli unsurlardan bir tanesidir. İç mekânın 1şık alması, havalandırılması, mekândaki çarpıklığın giderilmesi gibi nedenlerle çeşitli biçimlerde çıkmalar yapılmıştır. Genellikle sofanın plandaki uzantıları olan çıkmalar, plan şemasının dışa yansımasıdır ve cephede hareketlilik oluşturur. Çıkmalar, yapıdan yapıya değişik biçim ve boyutta olabilmektedir (Urfalığlu, 2010).

Geleneksel Türk evinde katlara göre pencere düzenleri farkl1lık göstermektedir. Üst kat yol seviyesinden daha yukarıda olduğu için pencereleri daha büyük ebatlarda yapılmış, böylelikle yaşama mekânlarının aldığı 1şık daha çok olmuştur. Zemin katta ise servis mekânlarının bulunması, taşıyıcı sistemin yığma olması sebebiyle açıklıkların düşürülmesi ve mahremiyetin de etkisiyle küçük boyutlarda pencereler kullanılmıştır. Yaşama katında da 1sınma problemlerinden dolayı kışlık odalarda pencere boyutları küçük tutulurken, yazlık odalarda pencereler daha büyük boyutlarda yapılmıştır (Küçükerman, 2007). Geleneksel konutlarda sabit ve hareketli olmak üzere iki tip pencere ile karşılaşılmaktadır. Sabit pencereler genellikle üst katlarda renkli camlarla birlikte uygulanmıştır. Hareketli pencereler ise düşey sürgülü ya da kanatları açılan pencerelerdir. Pencerelerde bulunan kafesler ve kepenkler cepheye hareket veren önemli elemanlardandır (Perker, 2012).

Geleneksel konutlarda cephenin sıvalı ve boyalı olduğu durumlarda renkler, kaplamalı cephelerde ise düşey ve yatay doğrultudaki ahşap kaplamalar; cephenin sıvasız bırakılması halinde ise dolgu malzemesi ve dolgunun geometrik biçimi cepheyi oluşturan diğer önemli unsurlardır.

\section{Ovacık İlçesi ve Yerleşim Yeri Özellikleri}

Ovacık ilçesinin tarihi ile ilgili yapılan araştırmalara göre ilk yerleşimler M.Ö 2000-3000 yıllarında başlamıştır. Ovacık'ın da içinde bulunduğu Kuzeybatı Karadeniz bölgesine Paplagonialılar yerleşmiş olup, bölgede Paflagonya olarak isimlendirilmiştir. Paflagonya sınırları günümüzde; 
Karabük, Kastamonu, Sinop, Çankırı, Bartın illerinin yer aldığı bölgedir. Paflagonya bölgesi tarih boyunca Frigyalılar, Kimmerler, İskitler, Lidyalılar, Persler, Makedonya Krallığı, Pont Krallığı, Roma ve Bizans egemenliğine girmiştir (Gökoğlu, 1952).

1071 Malazgirt Zaferi'nden sonra Anadolu'da başlayan Türkleşme süreci, Paflagonya bölgesine de yayılmıştır. 11. yüzyılın sonu, 12. yüzyılın başında Kuzeybatı Anadolu Türkler tarafından fethedilmeye başlanmıştır (Ersoy, 2011). Emir Karatekin 1082 yılında Çankırı, Eflani, Ulus, Bartın, Kastamonu ve Safranbolu'yu da fethederek bir Türk Emirliği kurdu (Sakaoğlu, 1987). Daha sonraki dönemlerde bölgede; Danişmentliler, Çobanoğulları Beyliği, Umuroğulları ve Candaroğlu Beyliği hâkimiyetleri görülmektedir. 1389 yılında ise bölge toprakları Osmanlı hâkimiyetine geçmiştir.

Osmanlı döneminde Karabük yöresi Bolu sancağına bağlanmıştır. Bolu sancağı 16 kazadan oluşmaktadır. Karabük il sınırlarında bulunan coğrafyada, Taraklı-Borlu (Safranbolu), Viran-Şehir (Eskipazar-Ovacık çevresi) ve Yenice kazaları bulunmaktadır. Ovacık sınırlarını da kapsayan ViranŞehir; 48 haneli, geçimini tarım ve hayvancılıktan sağlayan bir kazadır. 17.yüzyılda Bolu Sancağının kaza sayısı 36'ya yükselmiştir. Bu durumda Ovacık bölgesinde Viran-Şehir, Şehabeddin ve Ulakderesi (Avlak) kazaları yer almaktadır. Bu kazalar 19. yüzyıla kadar varlığını sürdürmüştür (Ersoy, 2011).

Viran-Şehir, 1811 yılında yapılan düzenlemelerle Sancak haline gelmiştir. Bugünkü Karabük il sınırlarını kapsayan Viran-Şehir sancağının merkezi Tarakl1- Borlu (Zağfiranborlu) kazası olmuştur. Ovacık sınırlarında ise Şehabeddin ve Oğlakdere kazaları bulunmaktadır (Salname-i Devlet-i Aliye-i Osmaniye, 1855). Osmanlı taşra teşkilatında 1864 ve 1869-1870'li nizamnameler ile yapılan değişiklikler sonucu eyaletin yerini vilayet almıştır. 1869-1870'de yayınlanan "İdare-i Umumiye-i Vilayet Nizamnamesi” sonucunda vilayetler sancaklara, sancaklar kazalara, kazalar nahiyelere, nahiyelerde köylere ayrılmıştır (Acar, 2008). Ulak, Şehabeddin, Oğlakdere kazaları Ovacık nahiyesini oluşturmuştur. Ovacık nahiyesi Çankırı (Kengiri) Sancağının Çerkeş kazasına bağlanmıştır. 1869 yılında Ovacık nahiyesine bağlı 25 köy, 2145 hane bulunmaktadır (Ersoy, 2011).

Çankırı ili, Çerkeş kazasına bağlı nahiye olan Ovacık, 1959 yılında ilçe olarak Çankırı'ya bağlanmıştır. 1995 yılında Karabük'ün il olmasıyla Ovacık, Karabük iline bağlı bir ilçe olmuştur.

İlçe nüfusu 1980’li yıllarda köyleriyle birlikte yaklaşık 10000 iken, günümüzde merkez nüfusu 600, köyleriyle birlikte ise 5000 civarındadır. Ovacık ilçesi göç veren bir ilçedir. İş imkânlarının oldukça kısıtlı olması, tarım ve hayvancılığa verilen önemin azalması ve yetersiz sosyal imkânlar göçün başlıca sebepleridir (Yiğit, 2011). 
Ovacık ilçesi sınırlarında 42 köy ve 1 merkez mahalle bulunmaktadır. Arazi yapısının dağlık olmasından dolayı köyler çok sayıda mahalleden meydana gelmiştir. İlçede toplamda 137 yerleşim birimi yer almaktadır. Bu yerleşim birimlerinde yaklaşık 1700 hane bulunmaktadır. İlçede hiç kimsenin yaşamadığı, tamamen terkedilmiş yerleşim birimleri de vardır.

İlçede ve köylerde yer alan yapı türleri; konut, samanlık, ahır, ambar, köy odaları, cami, okul ve çeşme olarak gruplandırılabilir. İlçe merkezindeki yapıların çoğunluğu betonarme sistemle inşa edilmiş olsa da köylerdeki yapılar geleneksel yapım teknikleri kullanılarak inşa edilmiştir. Günümüz yaşam koşullarının etkisiyle işlevini yitirmeye başlayan geleneksel yapılar, yerlerini modern teknikler kullanılarak inşa edilen yapılara bırakmaya başlamıştır. Bu durumda köylerin geleneksel dokusuna zarar vermektedir.

Geleneksel yapım teknikleri kullanılarak inşa edilen konutlarda taşıyıcı sistem olarak çoğunlukla ahşap çatkı sistem kullanılmıştır. Yapılarda kullanılan bir diğer taşıyıcı sistem ise çantı tekniğidir. Ahşap çatkı ve çantı tekniğinin bir arada kullanıldığı yapılar da mevcuttur. Kırsal alanlarda yer alan yapılarda elde edilmesi kolay olan ahşap, taş ve kerpiç en sık tercih edilen yapı malzemeleri olmuştur. Yapının hemen hemen her bölümünde ahşap malzeme kullanımı söz konusudur.

1944 yılında gerçekleşen Bolu-Gerede depreminde Ovacık ilçesi büyük hasar almıştır. Çok sayıda can ve mal kaybı yaşanmıştır. Bu depremin ardından yıkılan yapıların yerlerine yörede yetişmiş yapı ustaları tarafından yeni yapılar inşa edilmiştir.

\section{4. Çalışma Alanında Geleneksel Konutlarda Cephe Düzeni}

Bölgede yer alan geleneksel konutlar, oldukça sade, süslemeden uzak cephe düzenine sahiptir. Cepheyi oluşturan temel elemanlar; kapılar, pencereler, çıkmalar ve üst örtülerdir. Cephede nadir kullanılan süsleme elemanları; pencere pervazları ve bazı kapıların üzerinde yer alan motifli boşluklar ile giriş kapılarının hemen üzerlerinde düşünülen kafesli ışıklıklar olarak nitelendirilebilir. Zemin kat cepheleri sağır tutulmuş, bazı konutlarda zemin katta bulunan ahır kısmındaki gübreleri dışarı atmak için kullanılan ve yörede "temek" adı verilen boşluk açılmıştır. Üst katlarda yer alan odalara ihtiyacı karşılayacak sayıda pencere boşlukları açılmış, bazı yapılarda çıkma yapılarak cepheye hareket kazandırılmıştır.

\subsection{Kat Sayısı}

Ovacık kırsal yerleşimlerinde geleneksel konutlar genellikle tek veya iki katlıdır. Üç katlı çok az sayıda konut örneğine rastlanılmıştır. Birden çok katlı konutlarda genellikle zemin katın, ahır veya 
depo olarak kullanıldığı görülmüştür. Eğimli arazi yapısından dolayı yüksek kottan bakıldığında yapılar tek katlı gibi görünürken, aslında iki veya üç katlıdır.

\subsection{Giriş Kapıları}

Ovacık geleneksel konutlarında yapılara ya doğrudan sokaktan girilmekte ya da sokaktan önce avluya girilerek konuta erişim buradan sağlanmaktadır (Şekil 1). Alt katın ahır olarak kullanıldığı bazı konutlarda ahır girişi ile konut girişi farklı iki kapıdan yapılmıştır. Bu tür konutlarda ahır kapısı iki kanatlı iken konutun yaşama mekânlarına girişi sağlayan kapı tek kanatlıdır.

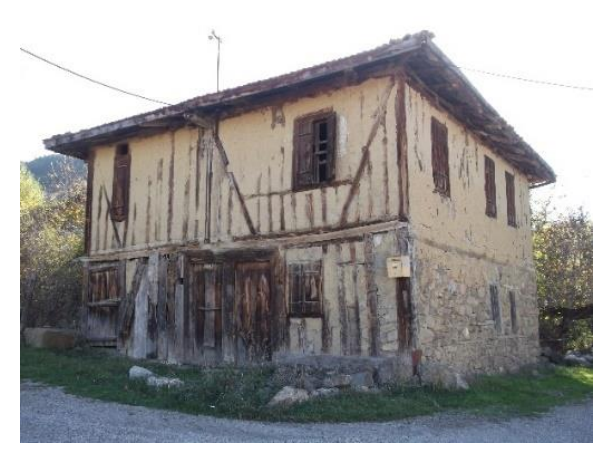

(a)

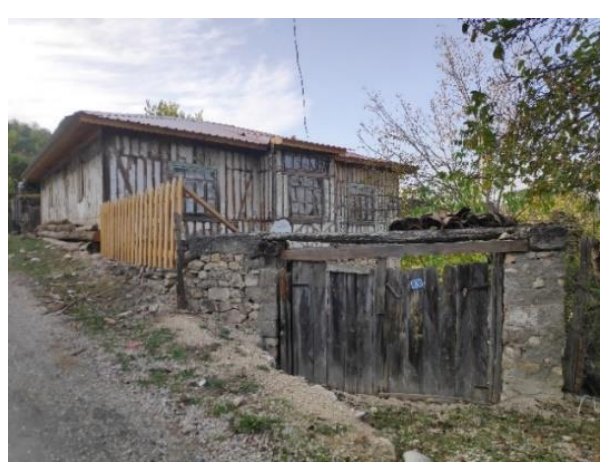

(b)

Şekil 1. Geleneksel konutlarda giriş örnekleri. (a) Başboyunduruk köyü, (b) Gümelik köyü.

Ovacık'ın eğimli arazi yapısından dolayı bazı konutlarda farklı iki kottan giriş sağlanmaktadır. $\mathrm{Bu}$ tür örneklerde, üst kotta ve sokağa bakan kısımda bulunan kapı ile doğrudan yapının 1. katına giriş sağlanırken; alt kotta ve farklı bir cephede bulunan başka bir kapı ise bahçeye açılmaktadır. Hem zemin katın hem de 1. katın girişinin aynı cepheden sağlandığı örneklerde bulunmakta olup, bu örneklerde 1. kata giriş, aynı cephede inşa edilmiş olan bir dış merdivenle sağlanmaktadır (Şekil 2).

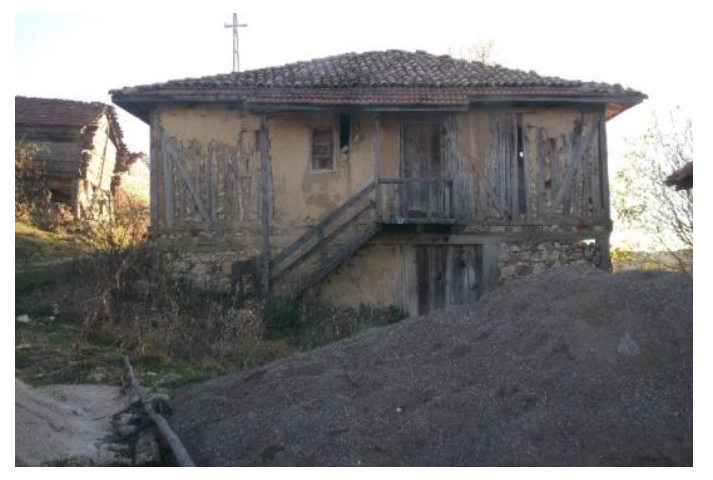

Şekil 2. Girişin 1.kattan merdivenle sağlandığı konut örneği (Sofuoğlu köyü). 
Çetin, E., Mutlu, M., Uluslararası Doğu Anadolu Fen Mühendislik ve Tasarım Dergisi / International Journal of Eastern Anatolia Science Engineering and Design (IJEASED)

(2021) 3(1):221-239

Özgün kapıların tamamı ahşap malzeme kullanılarak yapılmıştır. Ahşap çift kanatlı kapılarda her bir kanat genişliği yaklaşık 75-80 cm'dir. Kapı yüksekliği alt katın kullanım amacına göre değişmekte olup 180-220 cm arasındadır. Bazı nitelikli örneklerde giriş kapılarının üzerinde farklı desen özellikleri gösteren boşluklar bırakılarak iç mekânın az miktarda da olsa 1şık alması sağlanmıştır (Şekil 3). Bazı giriş kapılarının üzerinde girişi aydınlatmak amacıyla ahşap kafes yapılmıştır (Şekil 4). Ahşap kapılar; çakma veya tablalıdır. Bazı kapılarda metal kapı tokmakları bulunmaktadır. Kapı kilitleri ağaç kilit şeklinde, olup her kapının kilidi kendine özgüdür.

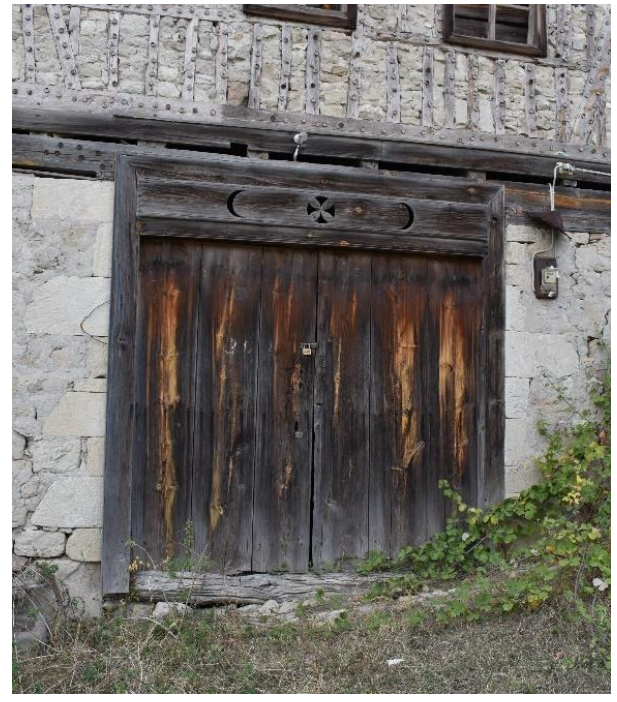

(a)

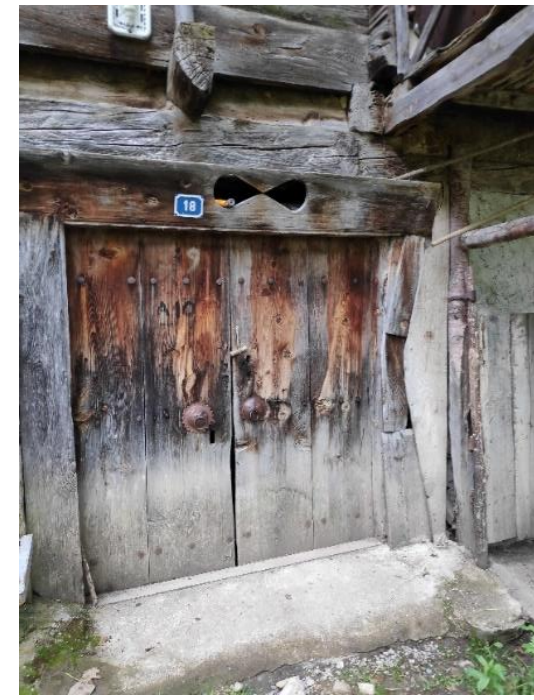

(b)

Şekil 3. Giriş kapılarının üzerindeki motifli boşluk örnekleri. (a) Boyalı köyü, (b) Dudaş köyü.

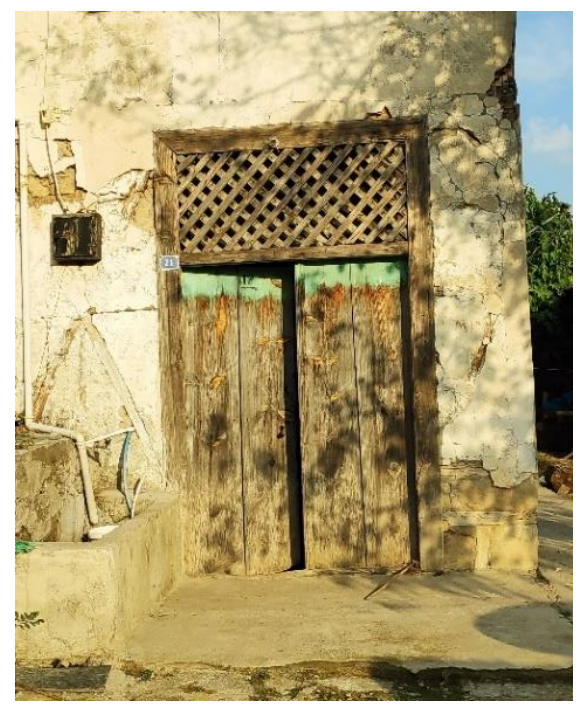

(a)

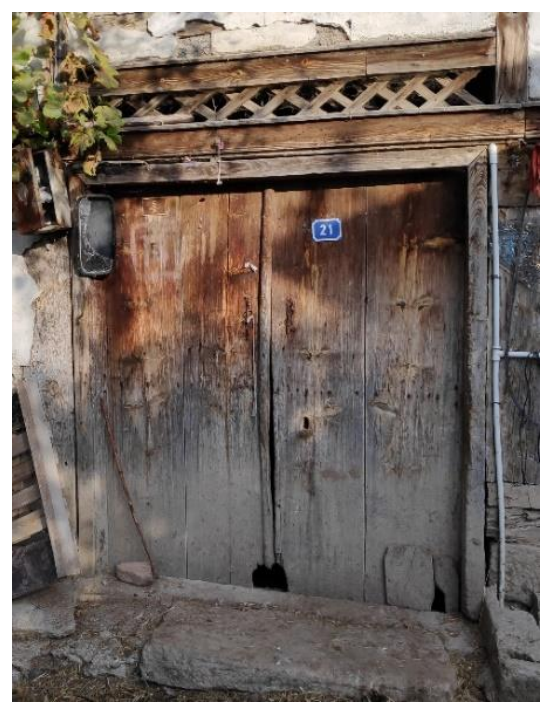

(b)

Şekil 4. Giriş kapılarında ahşap kafes kullanım örnekleri. (a) Boyalı köyü, (b) Küçüksu köyü. 


\subsection{Pencereler}

Zemin katları ahır veya depolama olarak kullanılan konutlarda zemin katlarda az sayıda pencere yapılmıştır. Konutların zemin katında yer alan ahır bölümünde küçük boşluklar bırakılarak bu boşluklardan hem ahırın havalandırılması sağlanmakta ve hem de bu boşluktan hayvanların gübreleri dışarı atılmaktadır. Bu açıklığa yörede "temek" denilmektedir (Şekil 5). Temek, mazgal pencere sisteminde yapılmış olup, içeriye doğru genişlemektedir. Zemin katında oda bulunan konutlarda ise, mahremiyet ve güvenlik açısından pencerelerde ahşap kapakların kullanıldığı görülmektedir.

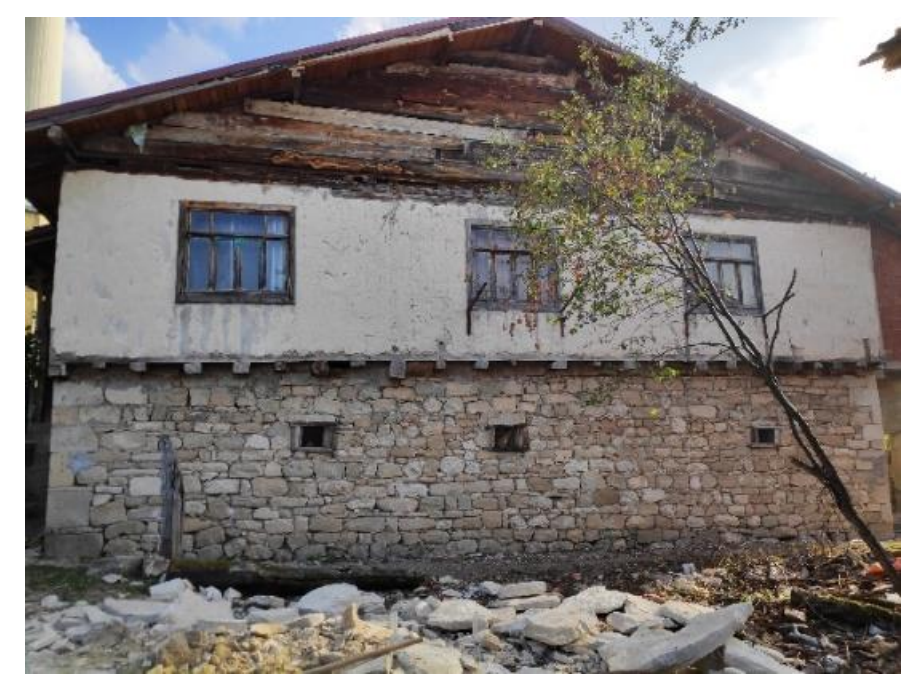

Şekil 5. Temek penceresi örneği (Çukur köyü).

Ovacık ilçesi kırsal yerleşimi geleneksel konutlarında kullanılan ahşap giyotin ve ahşap kanatlı pencerelerin çok büyük bir kısmı özgündür. Giyotin pencerelerin birçoğunda ahşap kapak kullanılmıştır (Şekil 6). Kanatlı pencereler, pencerenin genişliğine göre ahşap çıtalarla kanatlara ayrılmıştır (Şekil 7). En yoğun olarak dört kanatlı pencereler kullanılmış olup, bu pencerelerin ortadaki iki kanadı açılmaktadır. Bununla beraber, iki, üç veya dört kanatlı pencere örnekleri de görülmektedir. Pencereleri dıştan genellikle sade bir pervaz çevrelerken, bazı pencerelerin alt pervazları farklı formlarda biçimlendirilmiştir. 


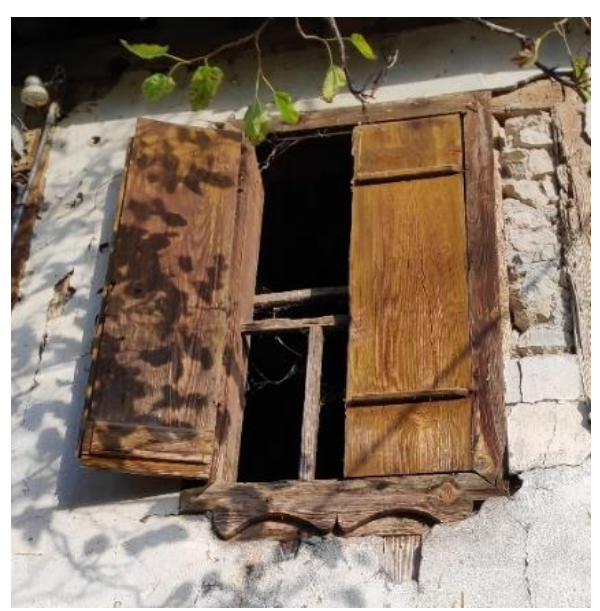

(a)

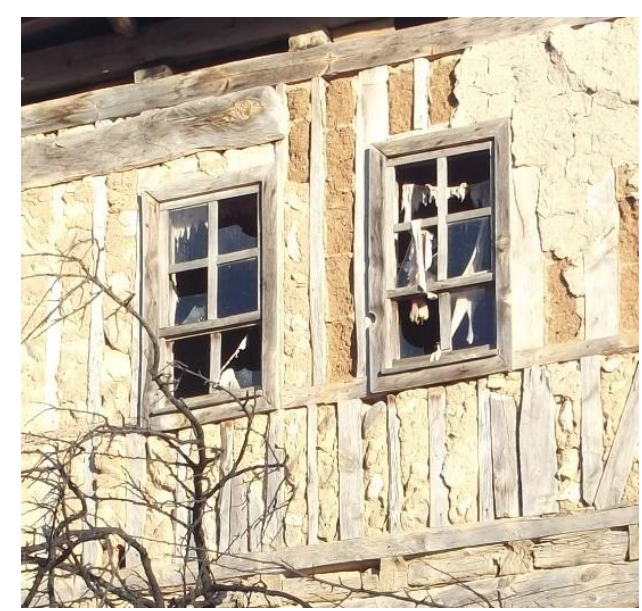

(b)

Şekil 6. Giyotin pencere örnekleri. (a) Küçüksu köyü (b) Sofuoğlu köyü.

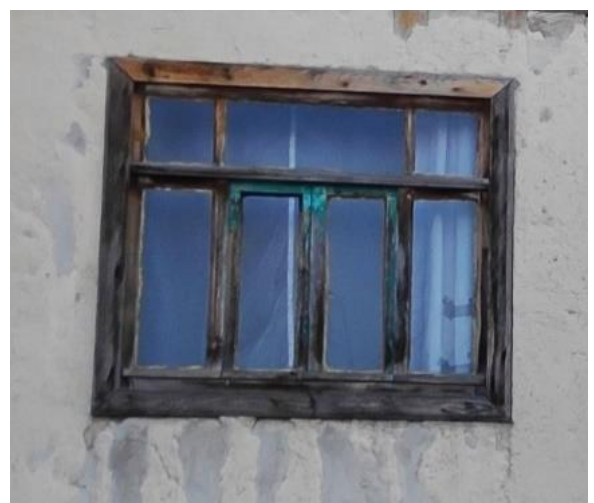

(a)

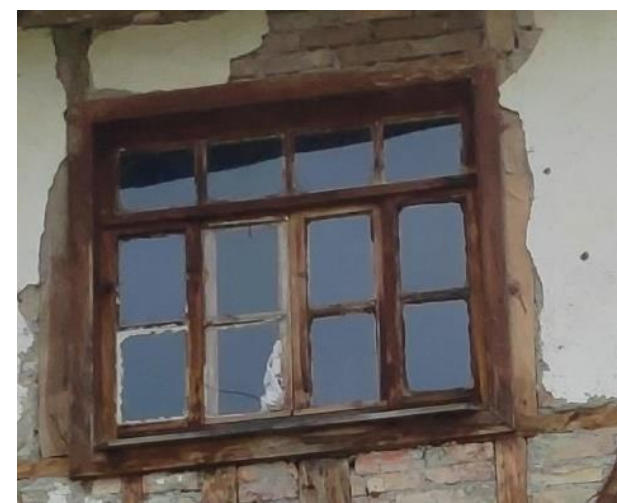

(b)

Şekil 7. Ahşap kanatlı pencere örnekleri. (a) Çukur köyü, (b) Dudaş köyü.

Üst katı oluşturan yaşama birimlerinde yörede “çardak” adı verilen sofalarda aydınlık mekânlar oluşturacak sayıda ve büyüklükte pencere düzenlemesi yapılmıştır. Çardağın çıkma şeklinde yapıldığı konutlarda çardak, dışarı bakan üç yüzünde yer alan pencerelerle aydınlatılmış ve sokağa farklı açılardan bakış sağlanmıştır. Odalarda ise, konut içerisindeki durumuna göre bir ya da iki cephesinde pencereler yer almaktadır. Çatı arasının kullanıldı̆̆ı bazı konutlarda çatı katında da pencere bulunmaktadir.

\section{4. Çıkmalar}

Ovacık kırsal yerleşiminde konutların üst katlarında; çardak ve abdestlik-hela bölümlerinde sıklıkla kapalı çıkma uygulamasına rastlanırken; kat boyunca devam eden çıkma çok az örnekte görülmüştür. Çardakta çıkma yapılan bölüm “eyvan” olarak adlandırılır. Eyvanın çıkma şeklinde 
yapılması sayesinde, çardağın daha iyi aydınlatılması ve dışarıyı izleme imkânı sağlanmıştır. Bazı konutlarda eyvanın çıkma yapan her üç yüzüne de pencere yapılmıştır (Şekil 8).

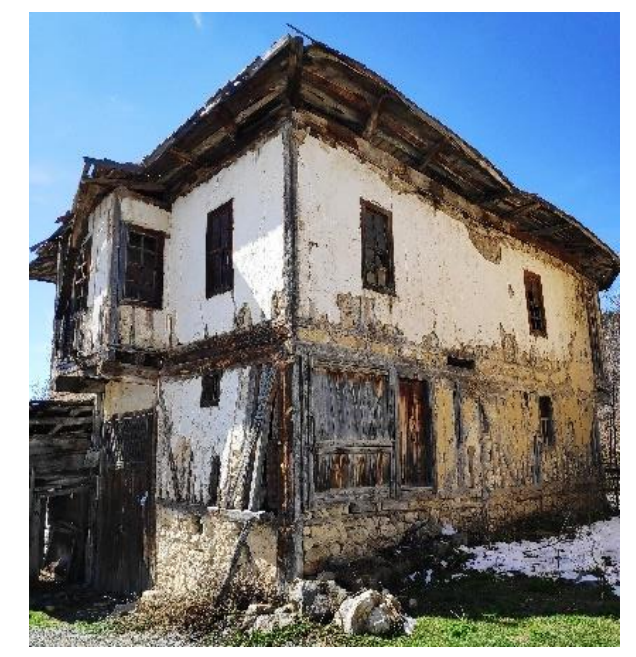

Şekil 8. Çardak mekânında çıkma örneği (Avlağıkaya köyü).

Islak hacimler genellikle konutun arka cephesinde yer almakta olup, ince uzun bir koridordan geçilerek ulaşılan mekânlardır. Çıkma olarak yapılan bu kısım, ahşap kaplama tahtalarıyla kapatılmıştır (Şekil 9). Örneklerin tamamında ahşap kaplamalar dikey olarak yapılmış olup, bazı örneklerde ise iç mekânın ışık alması amacıyla aralarında açıklık bırakılarak çakılmıştır.

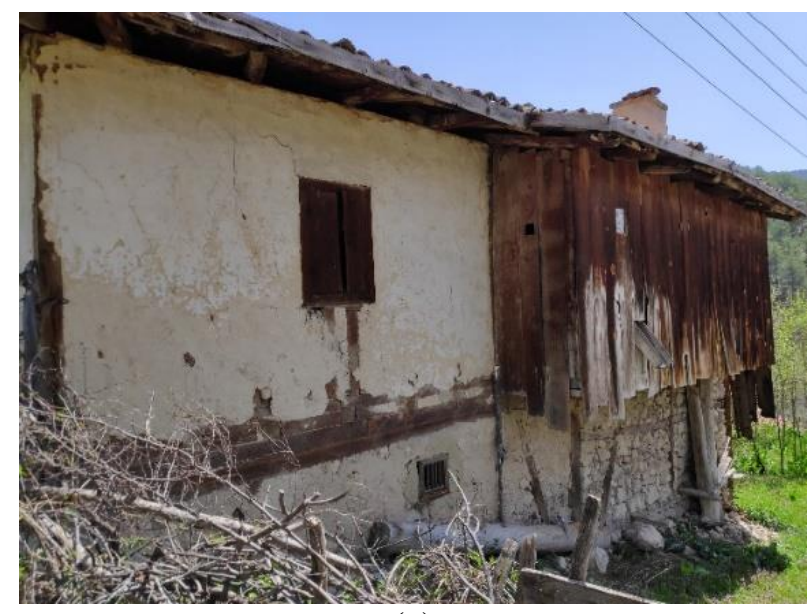

(a)

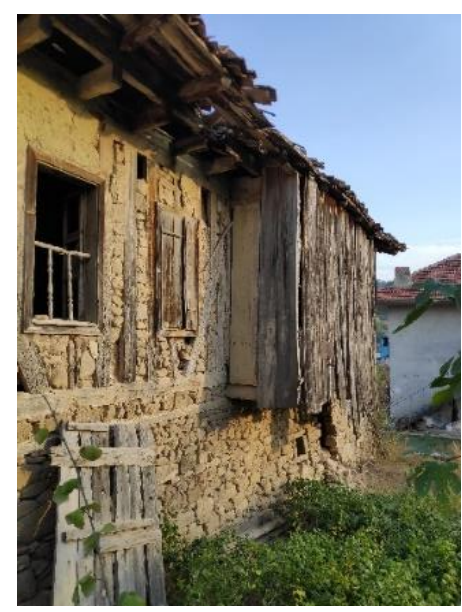

(b)

Şekil 9. Islak hacim kapalı çıkma örnekleri. (a) Dudaş köyü, (b) Boyalı köyü.

Çıkmaların büyük çoğunluğu bir mekâna dahil olan kapalı çıkma olarak yapılmışken, az sayıda örnekte balkon olarak kullanılan açık çıkma uygulaması bulunmaktadır (Şekil 10). Bu çıkmaları 
(balkonların) üzeri çatı ile örtülmüş, üst örtüyü taşıması için de ahşap dikmeler kullanılmıştır. Balkon korkulukları ahşap parçaların aralıklarla çakılmasıyla oluşturulmuş oldukça sade bir görünüme sahiptir. Bu çıkmaların bazıları alttan eliböğründelerle desteklenmişken, bazıları ise desteksiz olarak yapılmıştır.

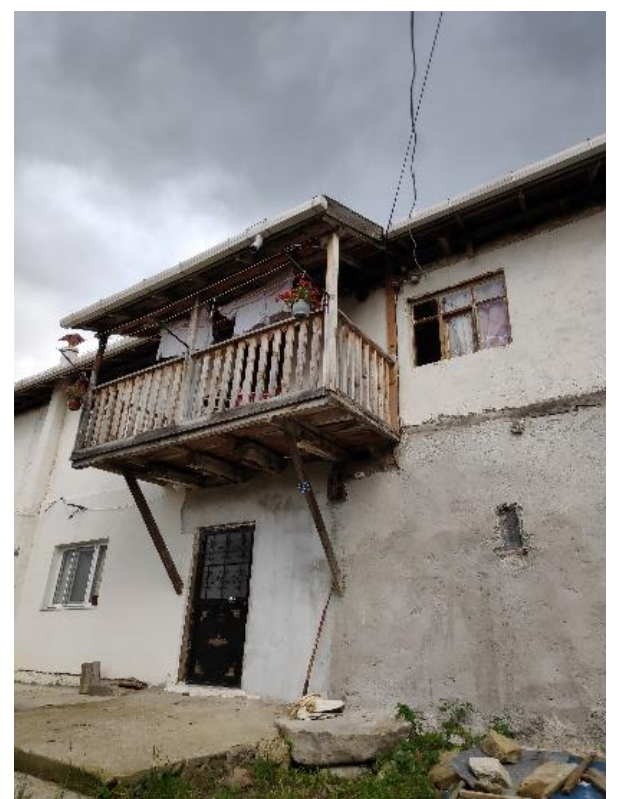

(a)

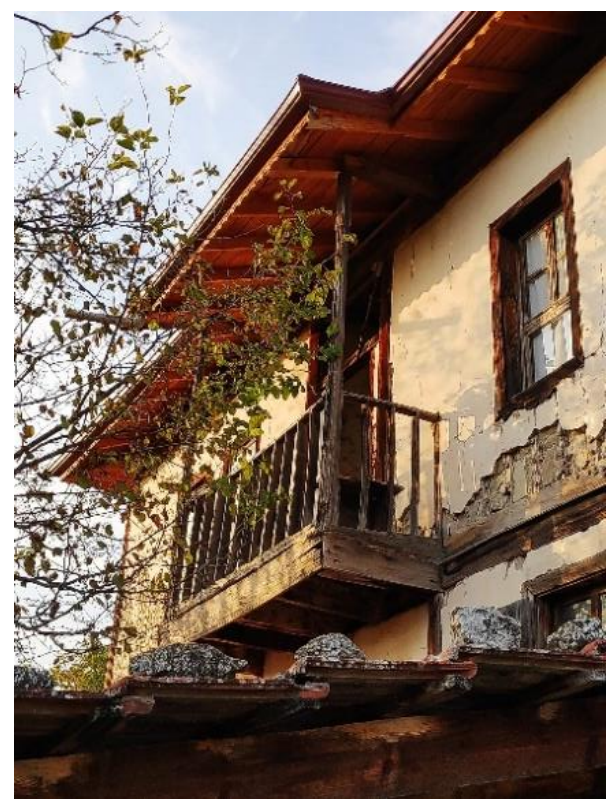

(b)

Şekil 10. Açık çıkma örnekleri. (a) Dudaş köyü, (b) Boyalı köyü.

Çalışma alanında tespit edilen çıkmalar statik bakımdan; konsol, konsol kirişli veya payandalı şekilde yapılmıştır (Şekil 11). Konsol çıkma, kat seviyesinde döşeme kirişlerinin uzatılmasıyla oluşturulur. Konsol kirişli çıkma, duvar yüzeyine dik döşeme kirişlerinin uzatılmasıyla oluşturulan çıkma çeşididir. Payandalı çıkma, çıkmayı taşıyan kirişlerin payandalarla desteklenmesiyle oluşturulur. Döşeme kirişlerinin direkt payandalarla desteklendiği veya payandaların çıkma kirişini desteklediği olmak üzere iki farklı şekilde payandalı çıkma yapılmaktadır. Döşeme kirişlerinin altı bazen kaplama tahtasıyla kapatılırken bazen de açıkta bırakılmıştır. 


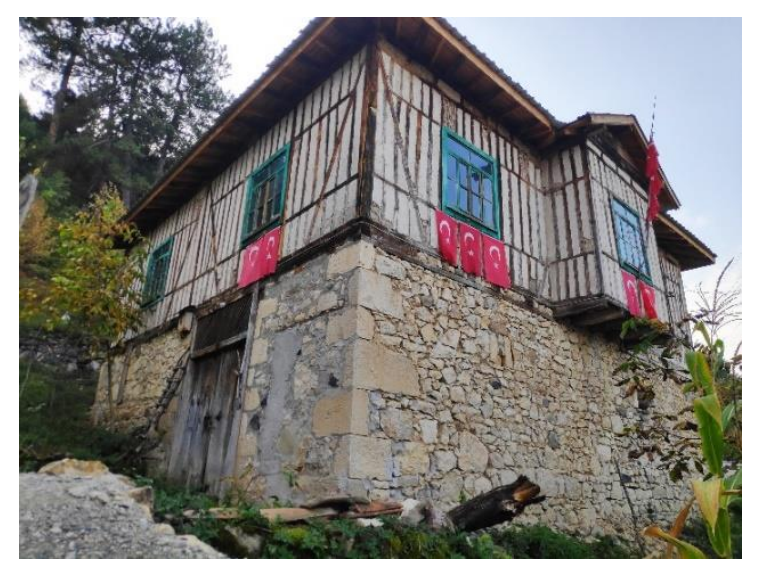

(a)

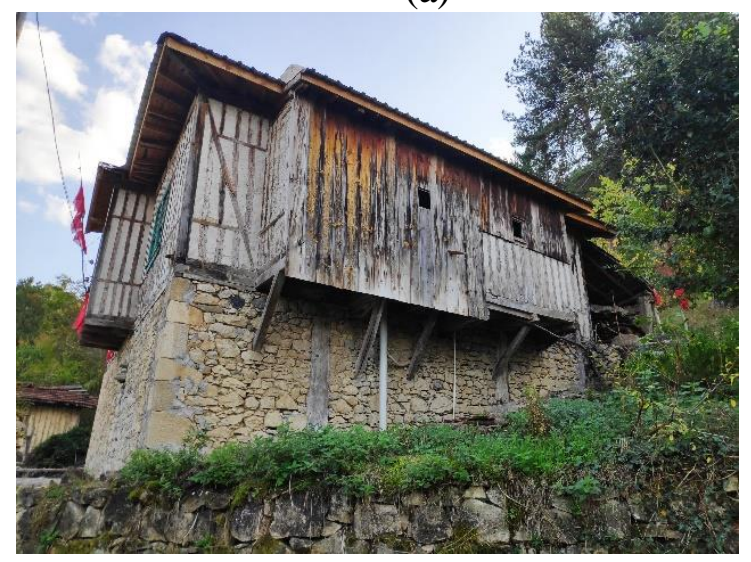

(c)

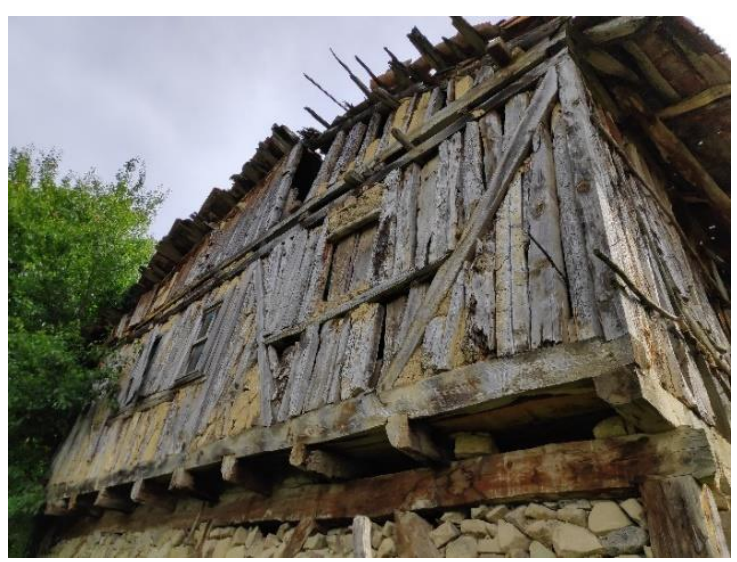

(b)

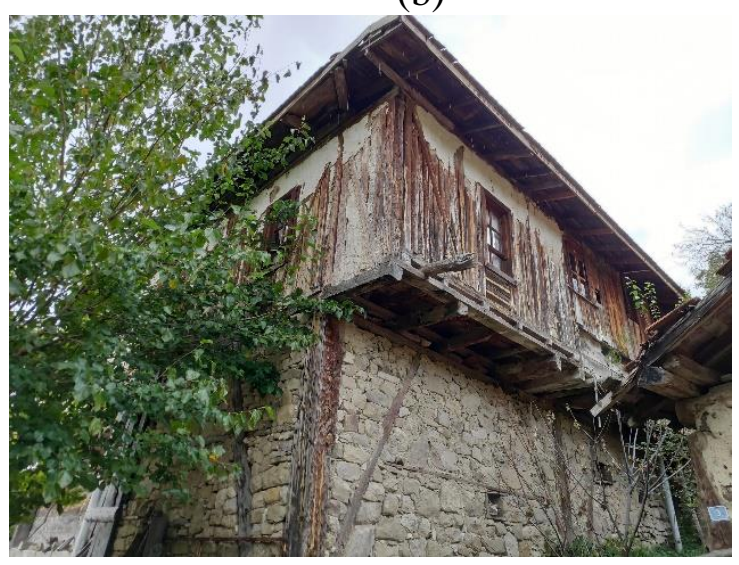

(d)

Şekil 11. Kapalı çıkma örnekleri. (a) Gümelik köyü, (b) Dudaş köyü, (c) Gümelik köyü, (d) Dudaş köyü.

\section{5. Üst Örtü}

Geleneksel Ovacık evlerinde; kırma çatı, üç omuz çatı ve beşik çatı olmak üzere üç farklı üst örtü uygulaması tespit edilmiştir (Şekil 12). Çok az sayıda konutta ise sundurma çatı biçimi kullanıldığı görülmüştür. Dikdörtgen plan şemasına sahip yapılarda genellikle beşik çatı, kareye yakın planlı yapılarda kırma çatı tercih edilirken, eğimli araziye oturan konutlarda ise üç omuz çatı tipi kullanılmıştır (Çetin, 2019). Balkonlu konutlarda çatı, balkonun üzerini kapatacak şekilde düzenlenmiştir. 


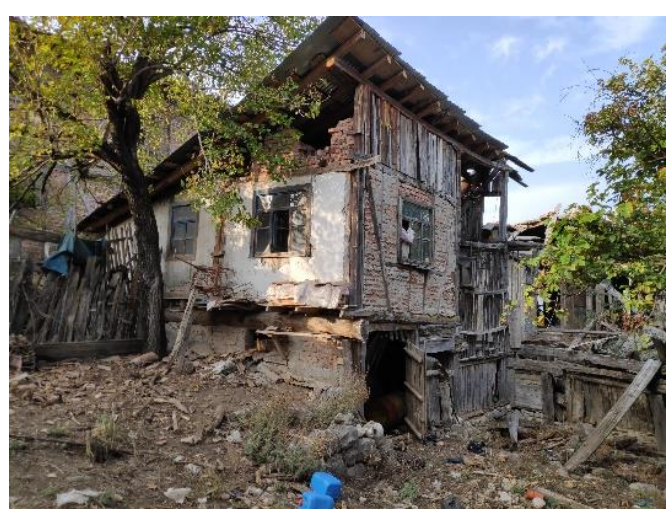

(a)

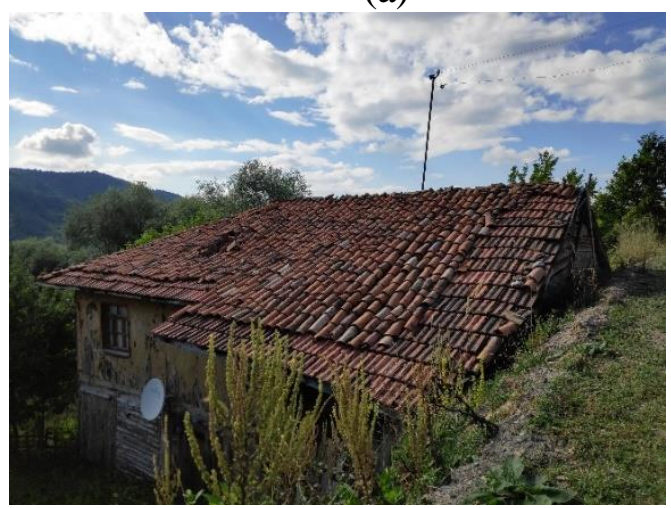

(c)

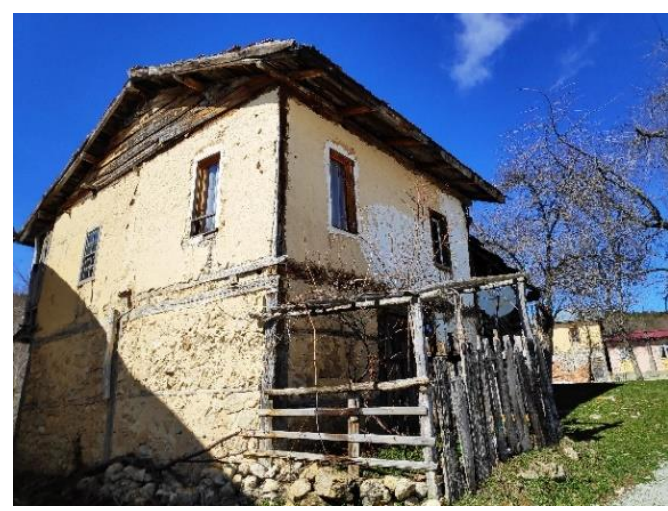

(b)

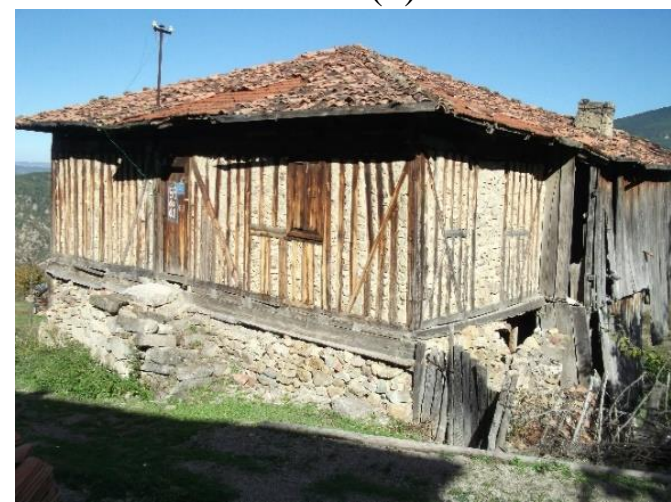

(d)

Şekil 12. Üst örtü kullanımına örnekler. (a) Küçüksu köyü, (b) Avlağıkaya köyü, (c) Dudaş köyü, (d) Beydini Köyü.

Üst örtü kaplama malzemesi olarak alaturka kiremit kullanılmıştır. Ancak zaman içerisinde konutlarda yapılan tadilatlarda alaturka kiremit yerine marsilya kiremit veya sac örtü kullanıldığı görülmektedir. Çatı saçakları, yapıyı yağmurdan koruyacak şekilde cepheden yaklaşık $60 \mathrm{~cm}$ taşırılarak yapılmıştır. Saçağın açık çıkmaların üzerinde bulunduğu durumlarda alttan payandalarla desteklenmiştir (Şekil 13). Konutlarda bacalar genellikle birleştirilmiş olup çatı üzerine çok sayıda baca çıkartılmamaya özen gösterilmiş ve yapımında harman tuğlası kullanılmıştır (Şekil 14).

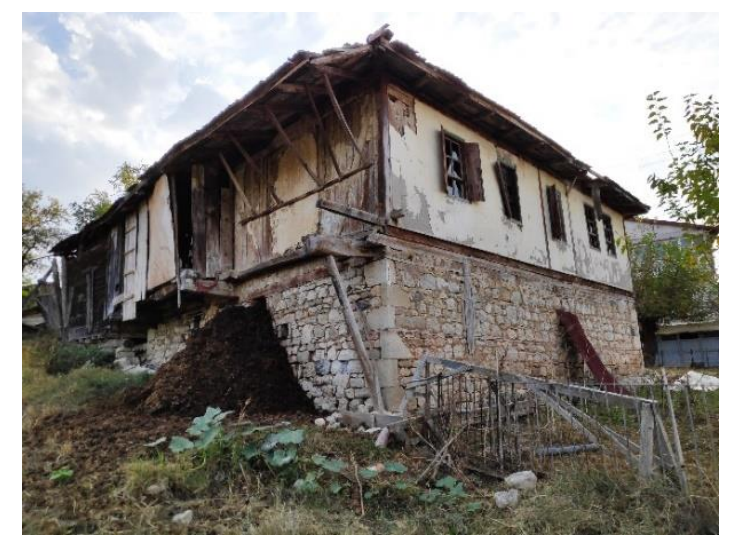

Şekil 13. Geniş çatı saçağının payandalarla desteklenmesi (Küçüksu köyü). 

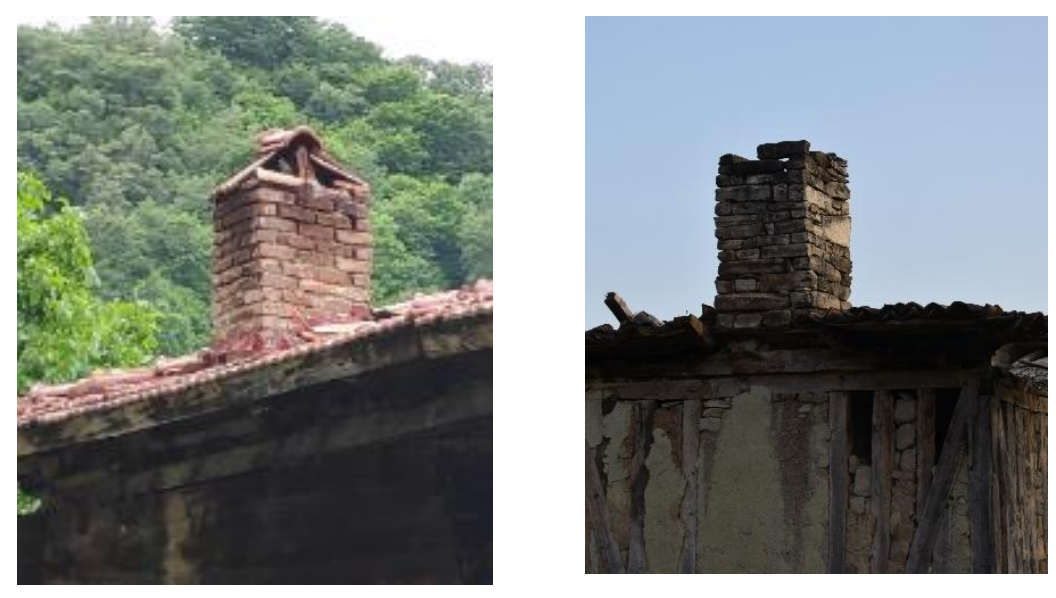

Şekil 14. Baca örnekleri.

\section{Geleneksel Ovacık Konut Cephelerinde Değişim ve Bozulmalar}

Geleneksel konutlar yapıldıkları tarihten günümüze kadar geçen zaman içerisinde çeşitli etmenlerden dolayı birtakım değişimler geçirmekte, geçirdikleri bazı değişimler de çeşitli bozulmalara sebep olmaktadır. Yaşantının değişmesi konutlarda fiziksel değişime neden olmakta, zaman içerisinde bakımsızlık nedeniyle fiziksel eskime süreci yaşayan konutlar bu duruma bağlı olarak bozulmaya başlamaktadır. Bu bozulmalar; biçimsel değişim ve buna bağlı bozulmalar, eleman ve malzeme kullanımındaki değişim ve bozulmalar, taşıyıcı sistemdeki değişism ve bozulmalar olarak üç grupta incelenebilmektedir (Perker, 2012).

Ovacık geleneksel konutlarında cephelerde görülen biçimsel değişim ve bozulmalar, zemin kattaki mekânların işlev değişikliğine bağlı olarak pencereler açılması veya var olan açıklıkların kapatılmas1, yeni kap1 yapılmas1, üst katlarda yer alan pencerelerin sayıs1, yerleri ve boyutları değiştirilmesi, ahşap pencere kapaklarının kaldırılması olarak sıralanabilir (Şekil 15). Cephelerdeki eleman ve malzeme kullanımındaki değişim ve bozulmalar ise ahşap pencerelerin sökülerek yerine pvc malzemeden üretilmiş pencerelerin takılması, ahşap kapıların yerine metal kapıların kullanılması, ahşap karkas arası dolgu malzemesi olarak kerpiç ve taş yerine modern tuğla, gaz beton veya briket kullanılması, özgün halinde sıva ve boya bulunmayan taş duvarların sıvanması veya boyanması, çatı kaplama malzemesi olarak sac levhaların kullanılması şeklindedir. Cephelerdeki taşıyıcı sistemde görülen değişim ve bozulmalar ise, taşıyıcı sistemde kullanılan elemanların zaman içerisinde fiziksel eskimeyle çeşitli bozulmaların meydana gelmesi şeklindedir. 


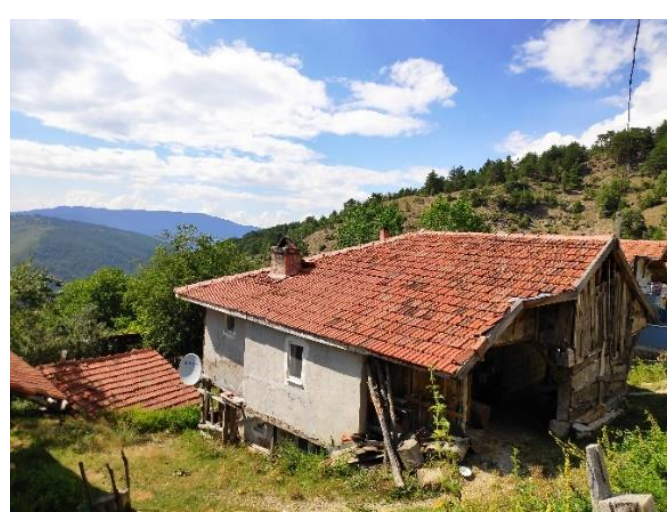

(a)

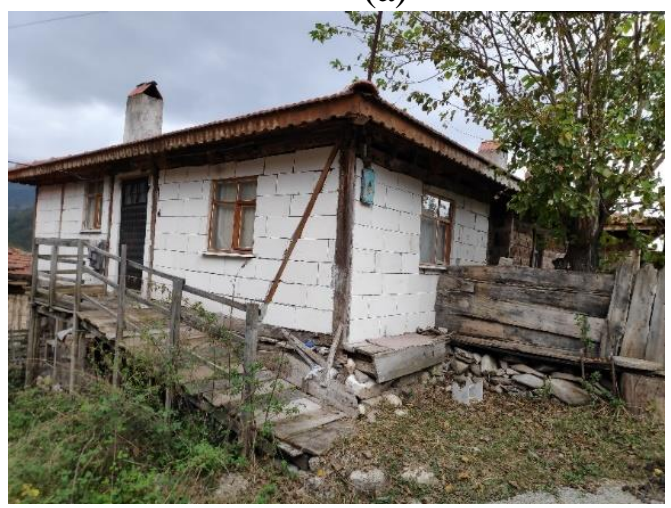

(c)

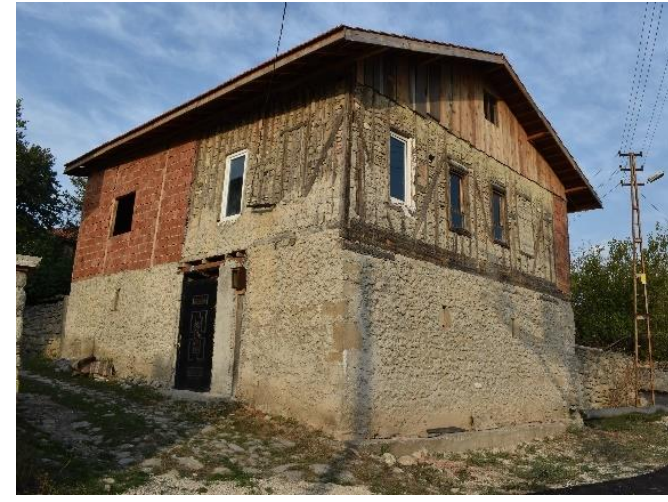

(b)

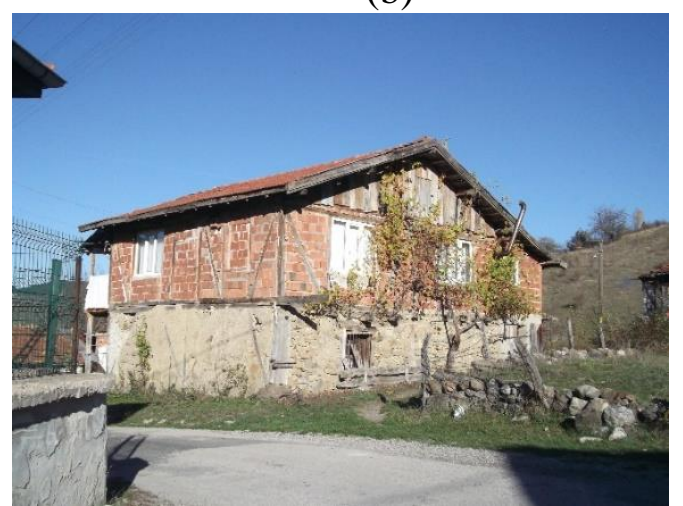

(d)

Şekil 15. Cephelerde meydana gelen değişim ve bozulmalara örnekler. (a) Dudaş köyü, (b) Boyalı köyü, (c)

Dudaş köyü, (d) Başboyunduruk köyü.

\section{Sonuç ve Öneriler}

Çalışmada Ovacık kırsal yerleşimlerinde yer alan geleneksel konutlar cephe düzenlemesi açısından kat sayısı, giriş kapısı, pencere, çıkma, üst örtü başlıkları altında detaylı olarak ele alınmıştır (Tablo 1). Geleneksel konutlar genellikle iki kattan oluşmaktadır. Konutların bazıları bahçe içerisinde yer alırken bazıları direk sokağa cephelidir. Konutların birden çok girişi olabilmekle beraber, genelde ahşap iki kanatlı kapılardan giriş yapılmaktadır. Ahşap giyotin veya kanatlı pencere kullanımı yaygındır. Çıkmaların çoğu konsol çıkma şeklinde olup yapının orta kısmında yer alan çardakta (sofada) görülmektedir. Hela ve abdestlik mekânları da konutun arka cephesinde çıkma şeklinde inşa edilmiştir. Konutun plan şemasına ve konumuna göre kırma veya beşik çatı kullanımı yaygındır. 
Tablo 1. Ovacık kırsal yerleşimlerindeki geleneksel konutlarda cephe elemanları örnekleri.

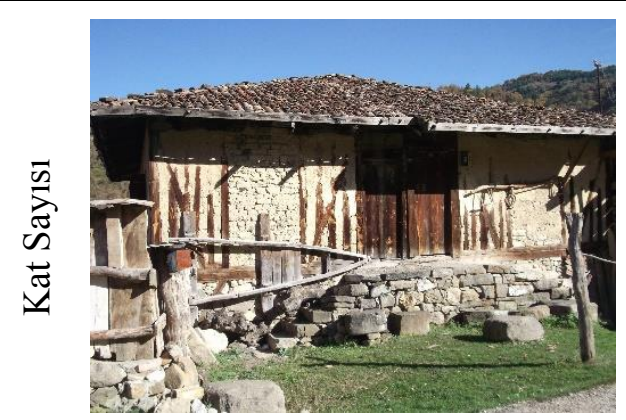

Dudaş Köyünden

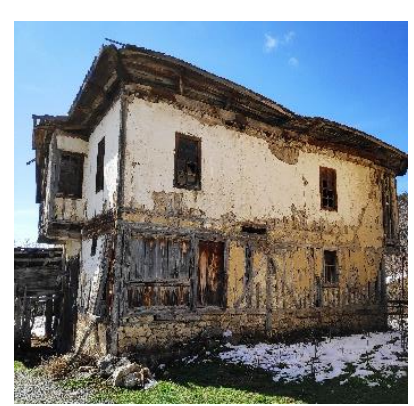

Avlağıkaya Köyünden

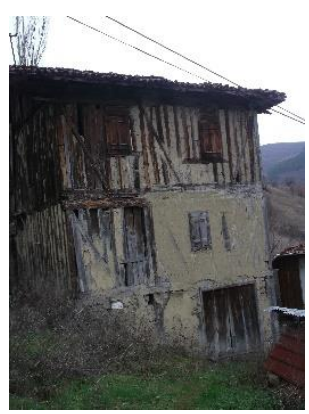

Dudaş Köyünden

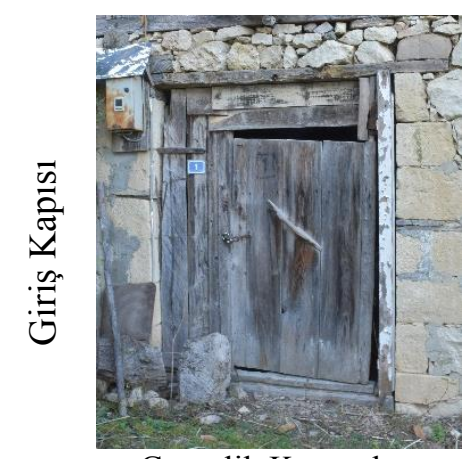

Gümelik Köyünden

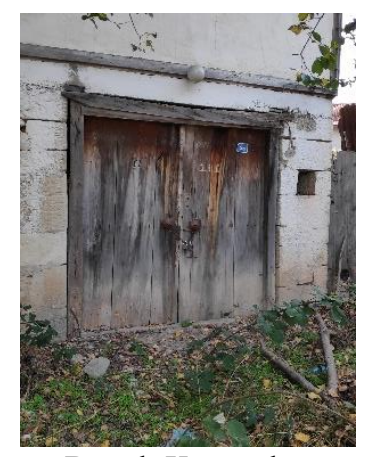

Boyalı Köyünden

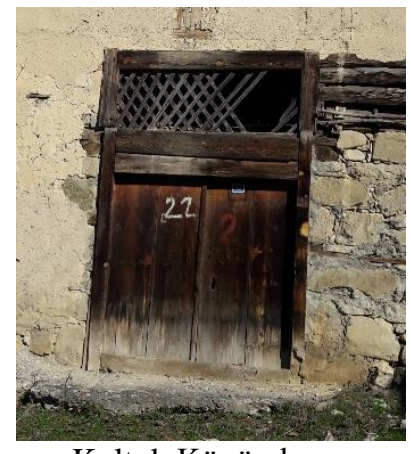

Koltuk Köyünden

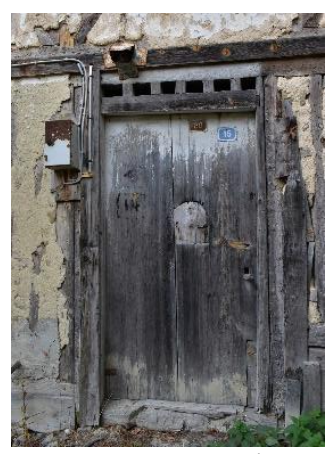

Yığınot Köyünden

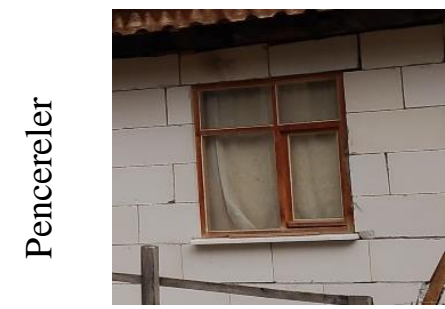

Dudaş Köyünden

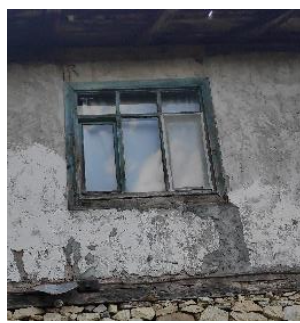

Gümelik Köyünden

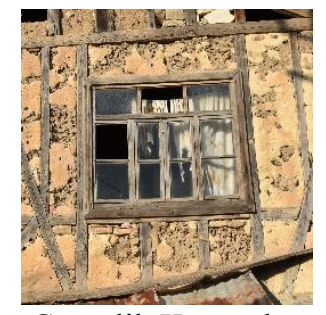

Gümelik Köyünden

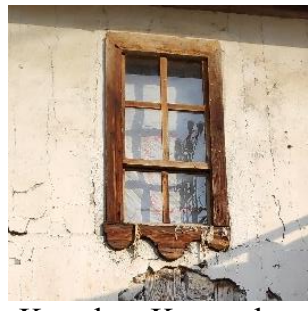

Küçüksu Köyünden

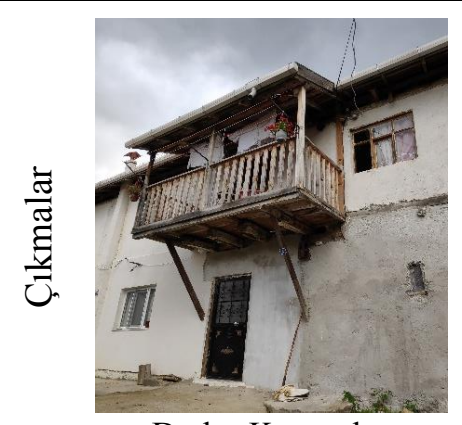

Dudaş Köyünden

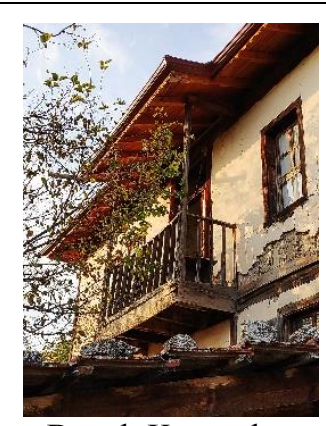

Boyalı Köyünden

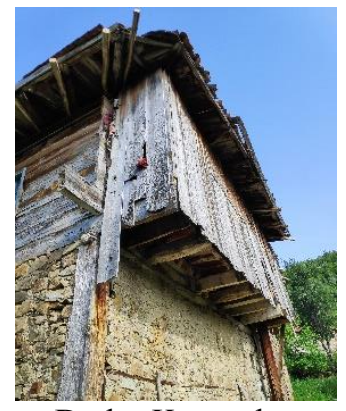

Dudaş Köyünden

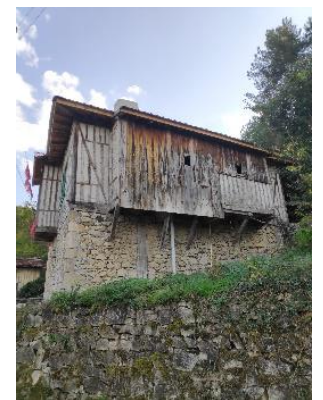

Gümelik Köyünden

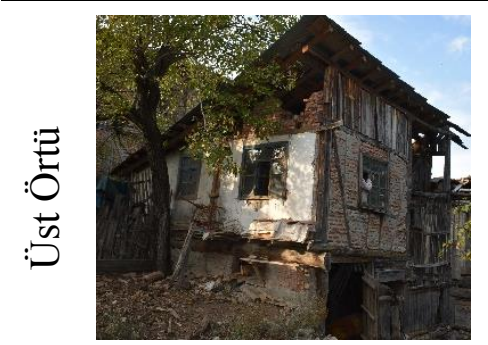

Küçüksu Köyünden

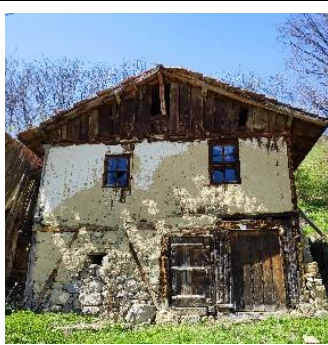

Dudaş Köyünden

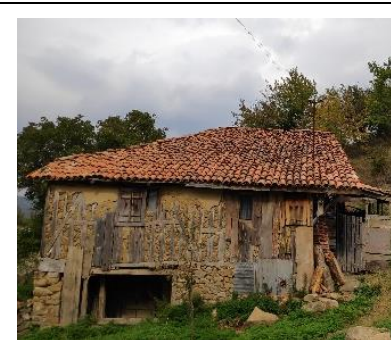

Dudaş Köyünden

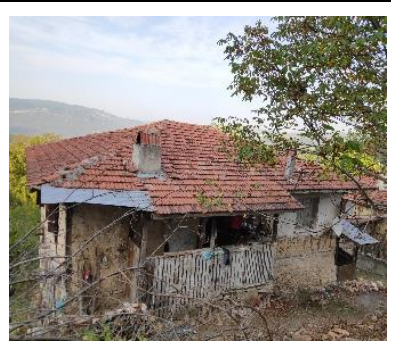

Ganibeyler Köyünden 
Konu hakkında yapılan literatür çalışmalarına bakıldığında Ovacık geleneksel konut mimarisi hakkında yeterli düzeyde çalışma yapılmadığı görülmektedir. Yapılan araştırmalar sonucu tescil altına alınmış konut örneği bulunmadığı, geleneksel yapıların korunmasına yönelik herhangi bir girişimin olmadığı görülmüştür. Geleneksel yapım teknikleri kullanılarak, bölgenin yerel yapı ustaları tarafından inşa edilmiş bu konutlar birer kültürel miras değeridir. Ancak bu yapılar sosyal ve ekonomik nedenlerden dolayı zamana yenik düşmeye başlamış, konutlarda değişim ve bozulmalar meydana gelmiştir. Bu değişim ve bozulmalar genellikle; zemin katlarda pencerelerin boyutlarının değiştirilmesi, yeni pencere ve kapılar açılması, üst kat pencerelerinde ahşap kapakların kaldırılması, özgün ahşap pencerelerin sökülerek yerlerine pvc pencerelerin takılması, duvar dolgu malzemelerinin değiştirilmesi, cephe bütünlüğünü bozacak şekilde sıva ve boya yapılması olarak sıralanabilir.

Ovacık geleneksel konutlarının cephelerindeki değişim ve bozulmaların en temel sebeplerinden biri de kullanıcıların günümüz ihtiyaç ve konfor koşullarına, konutların cevap verememesi olarak gösterilebilir. Kullanıcılar konutları günümüz şartlarına uyumlu hale getirmek isterken yapıya bilinçsizce müdahalelerde bulunmakta, bu da konutların özgünlüğüne zarar vermektedir. Geleneksel konutlarımızın korunabilmesi için gerekli önlemler alınmalı, yöre insanı bilinçlendirilmelidir. Ovacık, birçok özgün kırsal mimari doku özellikleri barındıran kırsal yerleşimlere sahiptir. Kültürel miras değerindeki mimari değerler yok olmadan kayıt altına alınmalı, özgünlüğünü kaybeden yapılar aslına uygun hale getirilmeli, yeniden işlev verilerek kullanımları sağlanmalı ve gelecek kuşaklara aktarılması için gerekli çalışmalar yapılmalıdır.

\section{Teşekkür}

Bu çalışmanın özet bildirimi “18-21 Kasım 2020’de Karabük Üniversitesi, Mimarlık Fakültesi tarafından Safranbolu'da Uluslararası Mimarlık Araştırmaları Sempozyumu (ReseArch'20)" kongresinde sözlü sunum olarak sunulmuş olup, kongre üyelerine teşekkür ederiz.

\section{Kaynaklar}

Acar, M., (2008). Tarihi Safranbolu Çeşmeleri, Ankara: Öztürkler Matbaa.

Çetin, E., (2019). Karabük İli Ovacık İlçesi Dudaşs Köyü Örneğinde Kırsal Yerleşimlerdeki Geleneksel Konutların Incelenmesi. Yüksek Lisans Tezi, Karabük Üniversitesi, Lisansüstü Eğitim Enstitüsü, Karabük.

Eldem, S., H., (1984). Osmanlı Dönemi Türk Evi, İstanbul: Türkiye Anıt Çevre Turizm Değerlerini Koruma Vakfi.

Ersoy, H., L., (2011). Karabük'ün Köyden Kente Dönüş Öyküsü Karabük Tarihi, Karabük: Karabük Valiliği İl Özel İdaresi Kültür Yayını.

Gökoğlu, A., (1952). Paphlagonia, Kastamonu: Doğrusöz Matbaas1.

Küçükerman, Ö., ve Güner, Ş., (1995). Anadolu Mirasında Türk Evleri, İstanbul: T.C. Kültür Bakanlığı Yayınları. 
Özköse, A., Yıldırım, M. N., Uslu, E., Çetin, E., (2018, Ekim). Ekolojik Değerlerin Sürdürülmesinde Kırsal Değerlerin Korunmasının Önemi ve Karabük-Ovacık Avlă̆lkaya Köyü Örneğinde Bir "Eko-Müze" Deneme Projesi, Dicle Üniversitesi 1. Uluslararası Mimarlık Sempozyumu, Diyarbakır, s. 1274-1290.

Perker, S., Z., (2012, Nisan). Geleneksel Cumalıkızık Konutlarında Cephe Özellikleri ve Günümüzdeki Durum, 6. Ulusal Çatı \& Cephe Sempozyumu (s. 1-10). Bursa: Uludağ Üniversitesi Mühendislik ve Mimarlık Fakültesi.

Sakaoğlu, N., (1987). Amasra'nın üç bin yılı, Zonguldak: Zonguldak Valiliği.

Salname-i Devlet-i Aliye-i Osmaniye, (1855).

Urfalıŏlu, N., (2010). Antalya, Isparta ve Burdur Evlerinde Cephe Biçimlenişi, Antalya: Suna-İnan Kıraç Akdeniz Medeniyetleri Araştırma Enstitüsü Yayınları.

Yiğit, G. K., (2011). Ovacık (Karabük) İlçesinin Nüfus Özellikleri. Electronic Turkish Studies, 6(2), 523-536. 